\title{
10. SITE 311: HAWAIIAN MAGNETIC LINEATIONS
}

\author{
The Shipboard Scientific Party ${ }^{1}$
}

\author{
SITE DATA \\ Date Occupied: 27 September 1973 (0325) \\ Date Departed: 28 September 1973 (2242) \\ Time on Site: 43.3 hours \\ Position: $28^{\circ} 07.46^{\prime} \mathrm{N}, 179^{\circ} 44.25^{\prime} \mathrm{E}$ \\ Water Depth: 5775 corrected meters (echo sounding) \\ Bottom Felt With Drill Pipe At: 5780 meters below rig floor \\ Penetration: 37 meters \\ Number of Holes: 1 \\ Number of Cores: 5 \\ Total Length of Cored Section: 37.0 meters \\ Total Core Recovered: 19.0 meters
}

\section{BACKGROUND AND OBJECTIVES}

Site 311 was selected as a place where two important objectives might be reached by a single hole: to date the young end of the sequence of Mesozoic magnetic reversals and to date the episode of volcanism of a part of the Hawaiian Ridge northwest of Midway Islands. The trend of the Hawaiian set of magnetic anomalies intersects the trend of the Hawaiian Ridge at about the International Dateline. The site had been assigned to Leg 33, but in the readjustments of scheduling Pacific dates and ports that resulted from the delay in the installation of the heave compensator, the site was reassigned to Leg 32.

Larson and Chase (1972) used a magnetic-reversal block model based on the Phoenix lineations to correlate the Phoenix and Japanese lineations with the eastern portion of the Hawaiian lineations (anomalies M-1 to M-10). Site 311 on anomaly $\mathrm{M}-2$ on the Hawaiian lineation pattern will test the validity of this correlation. If this correlation is substantiated, Site 311 may be an important point for the calibration of the young end of the Mesozoic reversal time scale. This time scale, derived by Larson and Pitman (1972), predicts a

\footnotetext{
'Roger L. Larson, Lamont-Doherty Geological Observatory, Palisades, New York (Co-chief scientist); Ralph Moberly, Hawaii Institute of Geophysics, Honolulu, Hawaii (Co-chief scientist); David Bukry, U.S. Geological Survey, La Jolla, California; Helen P. Foreman, Oberlin College, Oberlin, Ohio; James V. Gardner, Scripps Institution of Oceanography, La Jolla, California; John B. Keene, Scripps Institution of Oceanography, La Jolla, California; Yves Lancelot, Lamont-Doherty Geological Observatory, Palisades, New York; Hanspeter Luterbacher, Esso Production Research-European, Begles, France; Monte C. Marshall, U. S. Geological Survey, Menlo Park, California; Albert Matter, Universitat Bern, Bern, Switzerland.
}

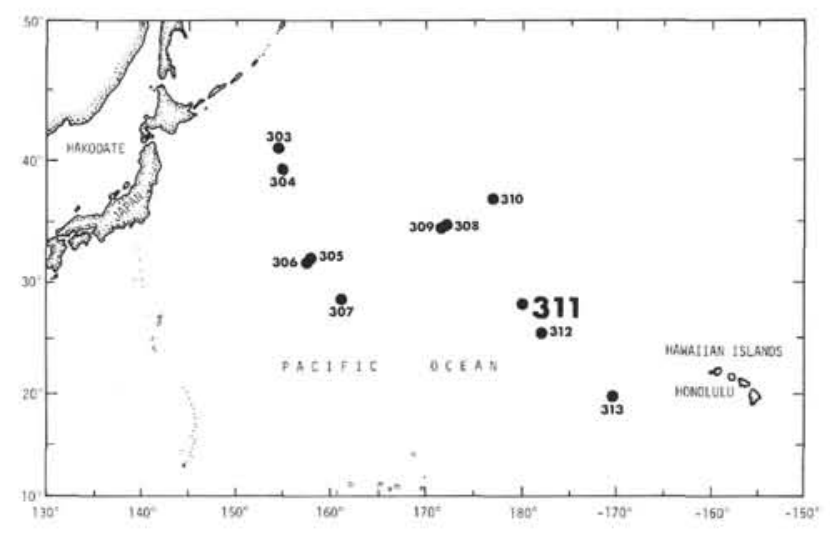

late Barremian to early Aptian basement age for Site 311 , about $110-115$ m.y. The results from this site also can be checked against a recent compilation of continental rock magnetic data for the Cretaceous (Irving and Couilliard, 1973). They predict an interval of normal magnetic polarity from 82 to 109 m.y. that occurred just after the late Mesozoic reversal sequence. The age of M2 should be just older than the old end of their long normal magnetic interval.

This study will also test the hypothesis of Larson and Pitman (1972), that the Late Cretaceous period between the "Cenozoic" and Mesozoic reversals was the time of a worldwide increase in sea-floor-spreading rates. This pulse has been evoked to explain a simultaneous pulse in batholithic emplacement around the Pacific basin (Larson and Pitman, 1972), the worldwide transgression of epicontinental seas during the Late Cretaceous (Hays and Pitman, 1973) and the Mesozoic orogenic history of Japan (Uyeda and Miyashiro, 1974). It has been noted by Irving and Couilliard (1973) to coincide with the Cretaceous normal interval, a coincidence which may be the most obvious aspect of a more general phenomenon that worldwide spreading rates are, in general, inversely proportional to the frequency of geomagnetic reversals (W. C. Pitman, III, personal communication).

Although the general progression of volcanism toward the southeast along the Hawaiian Archipelago has been recognized for over a century, there has been great current interest in the problem brought about by the stimulus of Wilson's (1963) hypothesis of the origin of linear volcanic chains by the movement of the lithosphere over a magma source, by the radiometric dating of Hawaiian volcanic rocks (McDougall, 1964; Funkhouser et al., 1968), by geophysical surveys by Scripps Institution of Oceanography (Shor, 1960; Normark and Shor, 1968) and the Hawaii Institute of Geophysics (Malahoff and Woollard, 1968; Furumoto et al., 1971), and the drilling on Midway Islands (Ladd et al., 1967). 
The archipelagic apron of the Hawaiian Ridge should include a sedimentary record of the episode of volcanism that built the adjacent seamounts of the chain. The interpretation of sediments recovered at Site 165, drilled west of the Line Islands in their apron, provided dates for the volcanism of a nearby seamount, from fossils within the turbidites composed of volcanic rock fragments that make part of the total section. Some events of the history of the seamount near Site 165 subsequent to its formation by volcanism were also disclosed by study of the fossils and sediment types in the turbidites above the part dominated by volcanic debris.

On Midway, where two core holes were drilled by a rig on a barge, the volcanic foundation of the atoll is about 18 m.y. old (M. A. Lanphere and G. B. Dalrymple, personal communication in Grommé and Vine, 1972). The seamount farthest west of Midway is a large unnamed one whose peaked summit (at about $270 \mathrm{~m}$ ) is near $28^{\circ} 50^{\prime} \mathrm{N}, 179^{\circ} 35^{\prime} \mathrm{W}$. Its apron covers the youngest Mesozoic magnetic anomaly. The seamount apparently does not have drowned reefs on its slopes, so Site 311 may not have any record of the history of the seamount after its time of origin, but the site is expected to provide the time of volcanism.

Among the variations of Wilson's theory, one proposed by Morgan $(1971,1972)$ is that melting anomalies, or "hot spots," exist in the earth's mesosphere and volcanic chains are the record of the passage of the lithospheric plates over the mesosphere. Morgan (1971, 1972) also proposed that the hot spot that formed the Hawaiian chain and is still active, previously had formed the Emperor Seamounts before a change in the relative motion of the Pacific plate and the mesosphere. However, perhaps the volcanism results from the progressive release of pressure (Jackson et al., 1972), perhaps the hottest parts of the asthenosphere is in counterflow toward mid-ocean ridges under the lithosphere (Moberly and Khan, 1969) so that lithosphere-to-mesosphere motion cannot be measured by dating volcanism, or perhaps the mechanisms of volcanism and motion are ones not yet proposed. The progression of dates between the active Hawaiian volcanoes and Midway is nearly but not exactly linear, but a linear rate cannot be continued to the next place now known, Kōko Guyot in the southern Emperor Seamounts, 50 m.y. at our Site 308 . The geometry and dates of Pacific plate motion (Clague and Jarrard, 1973) and of circumpacific events in the Cenozoic (Jackson et al., 1972) have been related to Hawaiian-Emperor rates. A major objective of Site 311 is to gain an additional date beyond Midway for the testing of these and other theories.

Beneath the turbidite debris from the Hawaiian Seamounts should lie the Mesozoic and early Cenozoic sediments that were deposited on the Pacific plate before the development of the Hawaiian chain in this area. Site 311 should have been formed south of the equator, so these sediments should have recorded both the subsidence from original ridge-crest elevations, and the subsequent passage of Site 311 across the equator. This site could have considerable bearing on this phase of the history of the Pacific plate as it is relatively isolated from the other old sites that are useful to this study.
The sediments at Site 311 probably contain cherts as do the other Mesozoic locations in the western Pacific that crossed the equator during the Cretaceous. The age and nature of these cherts will be studied to shed light on the equatorial transit of Site 311 and the factors involved in the chertification of these sediments.

The basaltic basement at Site 311 should be ridgecrest type tholeiite (commonly olivine-normative and very low in alkalies) with pillows and hyaloclastites which typify many previous DSDP basaltic sites. These rocks should be considerably altered because of their age and should be useful to geophysicists interested in refraction seismology, to geochemists postulating the composition of subducted crust and the transfer of transition elements from volcanic rocks to overlying sediments, and to rock magnetists interested in the direction, stability, and intensity of remnant magnetization.

\section{OPERATIONS}

We approached Site 311 (Figure 1) on magnetic anomaly $\mathrm{M}-2$ and the archipelagic apron of the Hawaiian Seamount chain generally from the north (Figure 2). We intersected the western flank of the large seamount about $250 \mathrm{~km}$ northwest of Midway Islands and turned south-southwest to run across its archipelagic apron to the site. The site is located near the south edge of a detailed survey by Kana Keoki and just south of M-2 on the C. H. Davis magnetic profile (Larson and Chase, 1972). The Kana Keoki profile at 0814, 16 July 1972 , shows $0.1 \mathrm{sec}$ of layered, but semitransparent material, overlying much darker reflectors. We passed over the site at full speed with our profiler showing only 30 meters of transparent sediment overlying much more opaque material. We continued on to the south-southwest for another $0.5 \mathrm{hr}$ in search of a better looking site. None appeared, so we made a Williamson Turn, slowed to 5 knots and returned approximately to the original site. At $1525 \mathrm{Z}$ on 26 September 1973, we

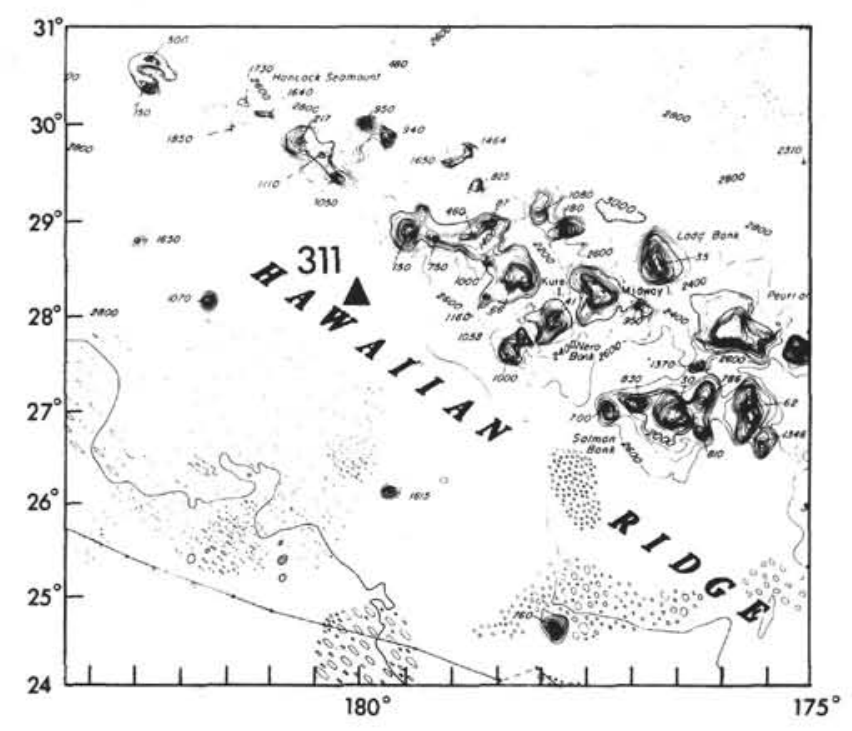

Figure 1. Bathymetry in the region of Site 311 (after Chase et al., 1971). Contour interval $200 \mathrm{fm}$ uncorrected. 


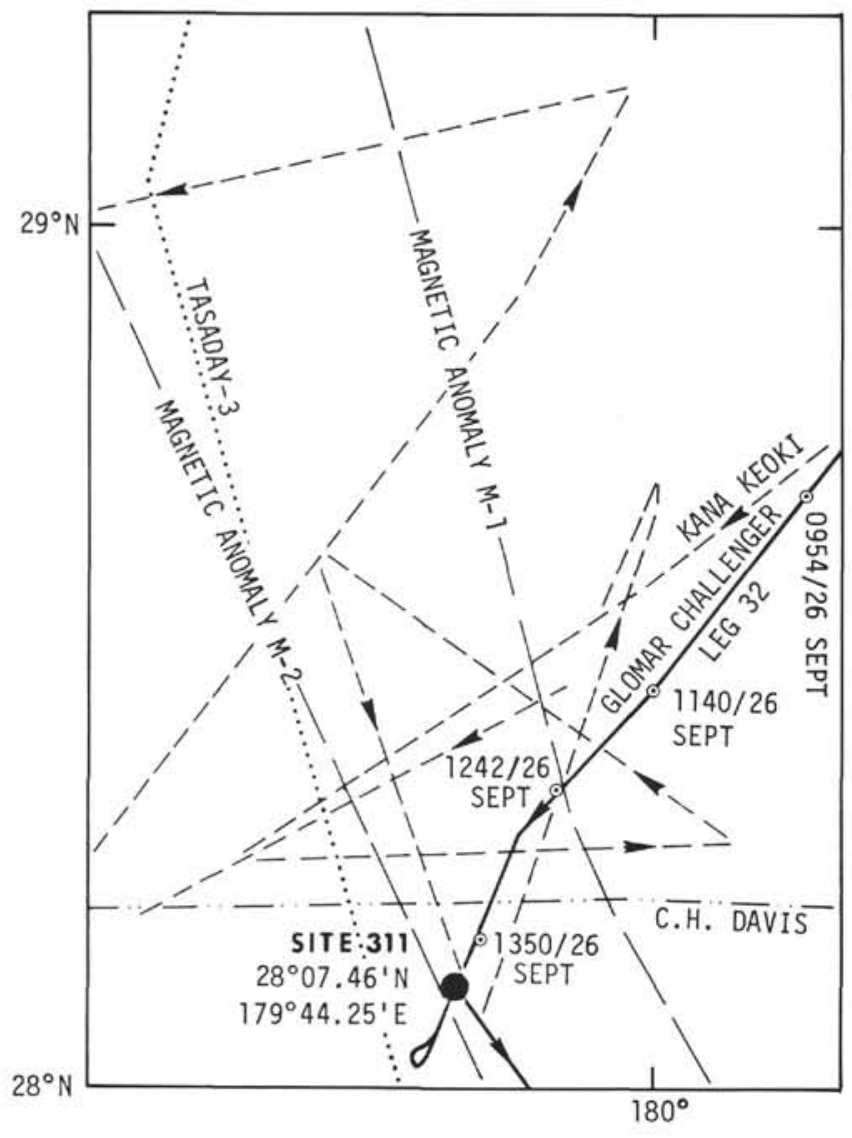

Figure 2. Track chart in the vicinity of Site 311. Solid track is Leg 32 Glomar Challenger, dashed track is Kana Keoki, dash-dot-dot track is C. H. Davis, dot track is Tasaday-3. Glomar Challenger navigation points indicated by open circles and annotated time/day-month. dropped the beacon on the run in 2798 uncorrected fathoms of water ( $5285 \mathrm{~m}$ corrected to the rig floor).

No sonobuoy was run on this site because of the shallow penetration that was achieved before breaking off the bottom-hole assembly. We steamed directly away from Site 311 toward Site 312 (Figure 3) without passing over the beacon.

It took $11 \mathrm{hr}$ to reach the ocean floor after starting to run in pipe, throughout which the ship was taking $7^{\circ}$ to $10^{\circ}$ rolls from the $1.5-2$ meter long period swells generated by the storm to the north that had blown us off of Hess Rise. We were forced to position the ship heading east into the 20 -mph eastern trade wind, thus putting the long storm swells on our port beam. About $2 \mathrm{hr}$ were lost running in pipe when the automatic pipe racker was shut down for repairs.

We appeared to tag the ocean floor at 5285 meters and rotated, but did not circulate, to cut a 4-meter core. When the core was brought on deck, we discovered we had recovered 8.1 meters of zeolitic pelagic clay. The mudline was established officially as 5280 meters, although the driller's indication of 5285 meters is at least an equally probable estimate. It is likely that additional material was crammed into the core barrel, causing the recovered section to be apparently thicker than the real stratigraphic interval.

A second core taken directly below the first one also consisted of soft zeolitic pelagic clay. Throughout this period the ship was maintaining its position well, but considerable rolls were still being taken.

While cutting the third core, a hard layer was encountered at 5301 meters. A small amount of penetration was made in this formation, and a partial core was recovered that revealed a lithified, brown mudstone. Core 5 took approximately $5 \mathrm{hr}$ to cut although the last few meters were penetrated very quickly. Core 5 is a

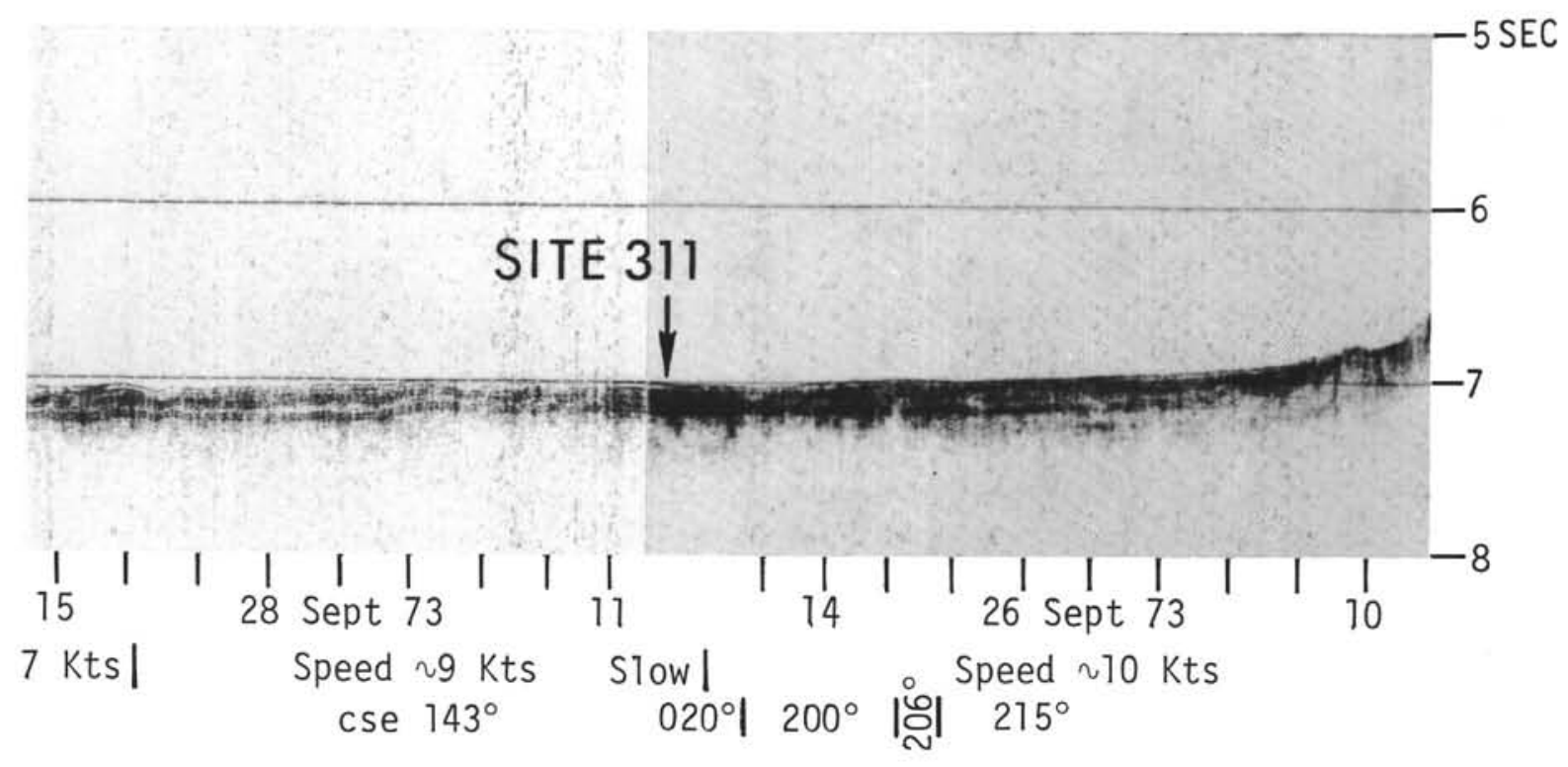

Figure 3. Seismic profiler section approaching and leaving Site 311. 
lithified volcanic turbidite similar to Core 4 . We appeared to penetrate very quickly for what should have been Core 6, but only the sinker bar and overshot were recovered, and the sinker bar was badly bent. When the drill string was weighed and the pump pressure tested, it became apparent that we had lost part of the bottomhole assembly.

The drill string was pulled up in $10 \mathrm{hr}$ to reveal that we had broken off the bottom-hole assembly at a lower bumper-sub connection. This is the same place the assembly was broken at Site 309 on Kōko Guyot, and the cause is the same; constant pounding of the brittle bottom-hole assembly on a hard formation without any lateral support. Table 1 is a summary of coring at Site 311.

The correlation of seismic reflection profiles with the drilling results shows that at this site during coring, like Site 310 and many sites on previous legs, soft sediment may have filled a core barrel before it penetrated a complete 9 to 9.5 meters. The echo-sounding depth, corrected to the rig floor, was 5785 meters, which also was where resistance was felt as the bit apparently met the sea floor. However, as the core was virtually full when recovered, the top of the cored interval was listed as 5780 meters, the depth when that joint of pipe was first lowered. The 16 meters between 5785 and 5801 meters (top of hard drilling) is closer to the PDR difference and is perhaps a truer thickness for the brown pelagic clay at Site 311 than the 21 meters listed in this report. There is little practical meaning to this evaluation at this site, not only because the $12-$ and $3.5-\mathrm{kHz}$ subbottom reflections vary by several meters over the region, but also because there are no useful fossils in the pelagic clay anyway. But it does point out once again the need for a $3.5-\mathrm{kHz}$ system and a drill-string pinger on Glomar Challenger for sites where information about the uppermost layers is critical.

\section{LITHOLOGIC SUMMARY}

The stratigraphic section drilled at Site 311 was continuously cored down to 37 meters, the total depth of the hole. The hole was drilled in 5780 meters of water. Recovery was good in Cores 1 and 2, but was poor in Cores 3,4 , and 5 . The poor recovery was due to high pump pressures required by the combination of lithification and shallow hole penetration. The composition of selected lithologies is shown in the smear slide summary (Table 2).
The section can be divided into two sedimentary units:

Unit $1-$ Zeolitic pelagic clay (0-13 m, Cores 1 and 2).

Unit 2-Volcanic turbidites $(13-37 \mathrm{~m}$, Cores 2 through 5).

\section{Unit 1-Zeolitic Pelagic Clay (Cores 1 and 2)}

This unit extends down to Core 2, Section 4, where the top of the underlying turbidite sequence occurs. The unit is a typical deep-sea brown, soft, zeolitic clay which is unfossiliferous except for rare fish debris. The zeolite phillipsite is abundant and is generally in the form of corroded laths with rare twins. The laths range in size up to $35 \mu \mathrm{m}$. There is a minor amount of yellowish-green volcanic glass.

At the base of Core 1 the upper part of a turbidite layer was recovered. It consists of semilithified, silt-size, cross-bedded volcanic debris. The volcanic material was mainly well-sorted angular palagonite grains (av. $50 \mu \mathrm{m}$ ) with lesser amounts of subhedral plagioclase and pyroxene (av. $40 \mu \mathrm{m}$ to $50 \mu \mathrm{m}$ ). The palagonite has now altered to clay and zeolite.

Beneath this turbidite, zeolitic clay occurs down to the basal contact of the unit. The contact is gradational due to drilling disturbance.

\section{Unit 2-Volcanic Turbidites (Cores 2 through 5)}

The upper part of this unit (13-21 m) consists of crumbly to semilithified turbidite layers with minor interbeds of brown zeolitic silty clay. Core 2 has several complete turbidites up to 1 meter thick. They are yellowish-brown in color and are generally calcareous in their upper part, whereas the lower, coarser fraction is more lithified. The carbonate is recrystallized calcite and contains burrows now filled with sparry calcite.

The lower part of this unit (21-37 m, Cores 3, 4, and 5) is lithified and there are no complete turbidites because of the poor recovery. In Core 3 a sequence of truncated cross-beds was sampled from a turbidite, but it appears that the finer upper parts of each turbidite have been washed away. Only at the base of Core 5 is there a finely laminated silty claystone representing the upper part of a turbidite.

In thin section, the light brown volcanic turbidites from Core 3 consist of brown palagonite, pale brown montmorillonite, zeolite (phillipsite), basalt fragments, plagioclase, and pyroxene grains. The clay and radiating crystals of zeolite form the cement as well as replacing

TABLE 1

Coring Summary

\begin{tabular}{|c|c|c|c|c|c|c|c|}
\hline Core & $\begin{array}{l}\text { Date } \\
\text { (Sept. } \\
\text { 1973) }\end{array}$ & Time & $\begin{array}{l}\text { Depth From } \\
\text { Drill Floor } \\
\text { (m) }\end{array}$ & $\begin{array}{l}\text { Depth Below } \\
\text { Sea Floor } \\
\text { (m) }\end{array}$ & $\begin{array}{l}\text { Length } \\
\text { Cored } \\
\text { (m) }\end{array}$ & $\begin{array}{l}\text { Length } \\
\text { Recovered } \\
\text { (m) }\end{array}$ & $\begin{array}{c}\text { Recovery } \\
(\%)\end{array}$ \\
\hline 1 & 27 & 2010 & $5280.0-5289.0$ & $0.0-9.0$ & 9.0 & 8.1 & 90 \\
\hline 2 & 27 & 2145 & $5289.0-5298.5$ & $9.0-19.5$ & 9.5 & 8.0 & 84 \\
\hline 3 & 27 & 2345 & $5298.5-5301.5$ & $19.5-22.5$ & 3.0 & 1.1 & 37 \\
\hline 4 & 28 & 0610 & $5301.5-5308.0$ & $22.5-28.0$ & 6.5 & 0.6 & 9 \\
\hline 5 & 28 & 1000 & $5308.0-5317.0$ & $28.0-37.0$ & 9.0 & 1.2 & 9 \\
\hline Total & & & & & 37.0 & 19.0 & 51.4 \\
\hline
\end{tabular}


TABLE 2

Smear Slide Summary, Site 311

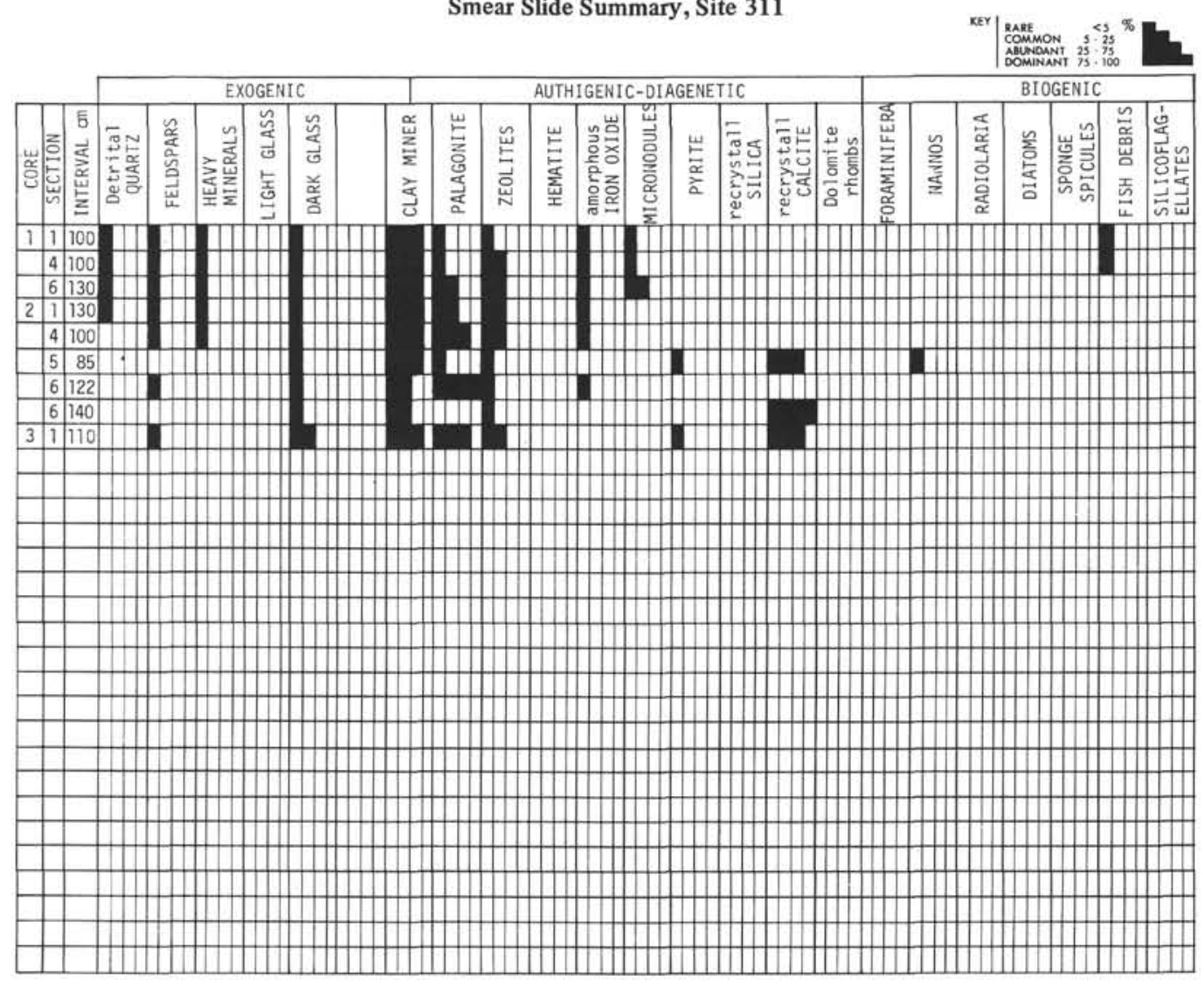

palagonite. The palagonite grains are angular whereas the basalt fragments, plagioclase, and pyroxene are subangular. In general, the grain size is less than $300 \mu \mathrm{m}$ (medium sand) and averages $200 \mu \mathrm{m}$ (fine sand).

In Cores 4 and 5 the color of the volcanic turbidites changes to grayish-green, the volcanic glass becomes less altered and the detritus is generally coarser. The color change is due to the occurrence of green montmorillonite (nontronite) and celadonite as authigenic phases and which, together with radiating sheaves of zeolites, form the cement. Fresh basaltic glass (R.I. 1.59) is common in Core 5 and occurs with palagonite (R.I. 1.48 to $1.50)$. In the hand specimen the basaltic glass is black, vitreous and hard, whereas the palagonite is softer and has a waxy luster. Fragments of basalt up to $2 \mathrm{~cm}$ in size occur in this core and they are rounded to subangular.

In thin section (Core 5) the basaltic glass and palagonite are angular and average $1 \mathrm{~mm}$ in size. Angular, unaltered plagioclase and pyroxene grains are common and are generally 100 to $200 \mu \mathrm{m}$ in size.

\section{Conclusions}

Due to lack of fossils, Unit 1 could not be dated; Core 3 from Unit 2, however, gave an age of mid-Oligocene (Sphenolithus distentus Zone, about 27 to 30 m.y.).

The general geologic history of this site commenced with a period of turbidite deposition followed by the slow accumulation of pelagic brown clay. The average sedimentation rate since mid-Oligocene is $0.7 \mathrm{~m} / \mathrm{m} . \mathrm{y}$.

The volcanic turbidites represent a time when the seamount to the north northeast was active. This seamount is part of the Hawaiian volcanic chain. The turbidites sampled define the end of the active volcanic period and thus the age to 27 to 30 m.y. is a minimum age for volcanic activity in this part of the chain. The site is some $70 \mathrm{~km}$ away from the nearest seamount of the chain and the sediments form the distal end of the archipelagic apron around the chain.

Lithification of the turbidites is due to the alteration of the volcanic glass in situ leading to the formation of clay and zeolite cement.

The calcareous material found at this site is also transported, and because of its small size $(<50 \mu \mathrm{m})$ forms the upper part of a turbidite when sampled. The carbonate is well burrowed, and this is further evidence that it forms the upper part of the turbidite. Despite its shallow burial depth, the carbonate has recrystallized and lithified.

\section{GEOCHEMICAL MEASUREMENTS}

Due to lithified sediments and shallow hole depth, only one interstitial water sample was taken from this site. The sample was from 7.5 meters below the sea floor. The $p \mathrm{H}$, alkalinity, and salinity for the sample are given in Table 3. 
TABLE 3

Summary of Shipboard Geochemical Data

\begin{tabular}{lcccccc}
\hline $\begin{array}{c}\text { Sample } \\
\text { (Interval in cm) }\end{array}$ & $\begin{array}{c}\text { Depth Below } \\
\text { Sea Floor }(\mathrm{m})\end{array}$ & $\begin{array}{c}\text { Punch- } \\
\text { in }\end{array}$ & $\begin{array}{c}\text { Flow- } \\
\text { through }\end{array}$ & $\begin{array}{c}\text { Alkalinity } \\
(\mathrm{meq} / \mathrm{kg})\end{array}$ & $\begin{array}{c}\text { Salinity } \\
(\%)\end{array}$ & Remarks \\
\hline Surface Seawater & & 8.24 & 8.33 & 2.37 & 35.5 & 8.34 \\
$1-5,144-150$ & 7.5 & 7.69 & 7.57 & 2.32 & 35.2 & 7.61 \\
\hline
\end{tabular}

\section{CORRELATION OF SEISMIC REFLECTION PROFILES WITH DRILLING RESULTS}

The drill did not penetrate sufficiently deep for us to determine the acoustic stratigraphy of the airgun records.

There is, however, a point of correlation on the 12$\mathrm{kHz}$ PDR record, which shows a strong subbottom reflection over nearly all of the archipelagic apron. The reflection also is prominent on $3.5-\mathrm{kHz}$ records of other ships. In the vicinity of Site 311 the reflector is about 7 or $8 \mathrm{fm}$ (about 13-15 m) below the bottom (Figure 4). It represents the top of the zeolite-cemented hard turbidites of Oligocene age.

\section{PHYSICAL PROPERTIES}

\section{Wet Bulk Density and Porosity of Soft Sediments}

The wet bulk density of the zeolitic pelagic clay and the upper, clayey volcanic turbidites was measured with the GRAPE. The sections measured were 2 and 5 in Core 1 and Sections 3 and 5 in Core 2. The density of the soft, severely disturbed clay decreases from $1.42 \mathrm{~g} / \mathrm{cc}$ at the top of Core 1 to $1.24 \mathrm{~g} / \mathrm{cc}$ at the top of Core 2, Section 3, and then increases to 1.30 at the base of this section. The density continues to increase in the stiff-semilithified, moderately severely disturbed, volcanic turbidites of Core 2, Section 5 , increasing from $1.45 \mathrm{~g} / \mathrm{cc}$ at the top to $1.57 \mathrm{~g} / \mathrm{cc}$ at the base of the section. A syringe

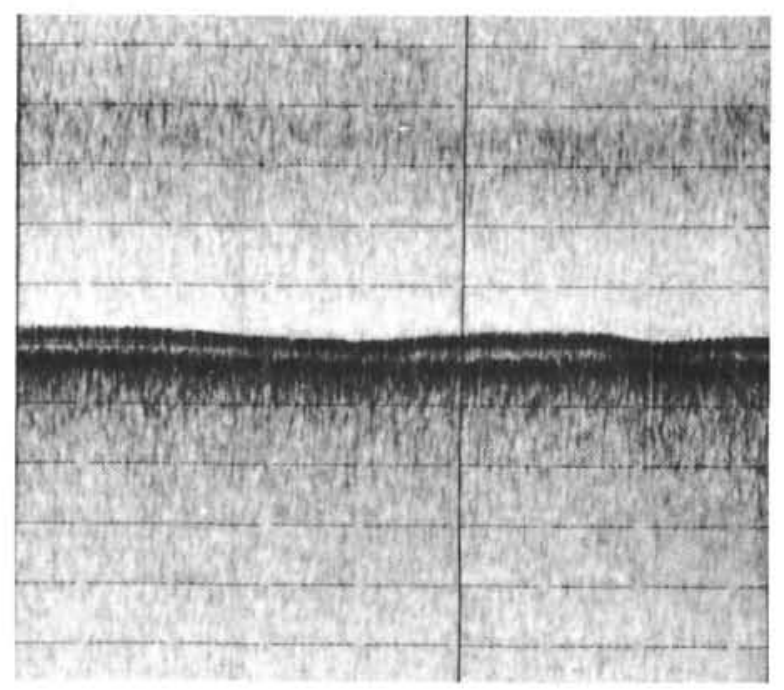

Figure 4. $12-\mathrm{kHz}$ PDR record of subbottom reflector with the Hawaiian archipelagic apron. sample was taken from each of the sections measured on the GRAPE as an independent measure of wet bulk density and porosity. The syringe densities and the values determined by the GRAPE agree, on the average, within several percent. The syringe data show that the wet bulk density variations are due largely to porosity differences. The porosity, therefore, varies inversely as the wet bulk density increasing from about $75 \%$ at the top of the pelagic clay to about $85 \%$ at the top of Core 2 , Section 3 , and then decreasing to $70 \%$ in the clayeysandy, volcanic turbidites at the base of Core 2, Section 5 . The fairly sharp increase in wet bulk density observed in the turbidites near the base of this section may be due, at least in part, to an increase in grain density. The porosity of these turbidites may be somewhat higher than $70 \%$.

\section{Sonic Velocity}

The compressional wave velocity, $V p$, of the soft, intensely disturbed, zeolitic pelagic clay recovered at this site is about $1.50 \mathrm{~km} / \mathrm{sec}$. The $V p$ in the semilithified to lithified volcanic turbidites is much higher and ranges from 2.2 to $2.5 \mathrm{~km} / \mathrm{sec}$ in the volcanic claystone to 2.5 to $3.4 \mathrm{~km} / \mathrm{sec}$ in the volcanic sandstone. A summary of physical properties for Site 311 is found in Figure 5.

\section{BIOSTRATIGRAPHIC SUMMARY}

The sediments recovered at Site 311 are deep-sea pelagic clays (Cores 1 and 2) and transported clastics of volcanic origin. Therefore, most of the samples examined are barren.

Only one sample in Core 3 could be dated as early late Oligocene based on coccoliths.

Fish remains (mainly teeth) are relatively common in Cores 1 and 2.

\section{Foraminifera}

The samples examined from this site contain no stratigraphically useful foraminifera.

Small numbers of simply structured arenaceous foraminifera ("Rhabdammina-Faunas") and fish remains occur in Cores 1 and 2.

\section{Coccoliths}

Coccolith assemblages are present in Cores 2 to 4 . In most samples Cyclicargolithus floridanus composes the assemblage and suggests only a post-Eocene age because of the turbidite origin of the sediment. A single sample in Core 3, Section 1, contains Dictyococcites bisectus and Sphenolithus distentus in addition to Cyclicargolithus floridanus. This assemblage indicates the early late Oligocene Sphenolithus distentus Zone (approximately 27 to 30 m.y.) 


\section{Radiolaria}

No Radiolaria were found in the five cores recovered from this site. Fish teeth were found in the dark brown clay of Core 2, Section 2, and may be present throughout the dark brown clay of Cores 1 and 2 .

\section{SUMMARY AND CONCLUSIONS}

The Sphenolithus distentus flora of Core 3 is early late Oligocene in age and indicates that the archipelagic apron of this part of the Hawaiian volcanic chain was built by the middle of the Oligocene. Undoubtedly the nearby Hawaiian Seamount was the source of the debris of fresh and palagonitized hyaloclastic glass, and lesser amounts of fresh hyaloclastic and reworked pyroclastic glass and lithic volcanic grains, because the turbidite beds are traceable on the Glomar Challenger and Kana Keoki reflection profiles to the slopes of the seamount.

The early late Oligocene age of about 27 to $30 \mathrm{~m} . y$. is a minimum one, because we did not penetrate to the initial volcanic turbidite beds.This age is at least $10 \mathrm{~m} . \mathrm{y}$. older than the currently accepted radiometric ages for Midway Islands. If the Hawaii-to-Midway progression of volcanic age is extrapolated west of Midway, the predicted age is only $2 \mathrm{~m}$.y. older than Midway. In fact, the age of volcanism determined by apron drilling at Site 311 is fairly close to a linear interpolation between Midway and Kōko Guyot. We conclude that the vector of relative motion between the Pacific plate and the melting anomaly has been constant in direction but that the rate was slower prior to the formation of Midway. This result also suggests that the vector change that occurred at the Emperor-Hawaiian "elbow" was more one of direction than rate.

The only history subsequent to the volcanic events at this site is the change from turbidite to pelagic sedimentation by Miocene time (Core 2).

Unfortunately, the loss of part of the bottom-hole assembly precluded any chance of dating the young end of the sequence of Mesozoic magnetic reversals. Figure 5 is a summary of data from Site 311 .

\section{REFERENCES}

Chase, T. E., Menard, H. W., and Mammerickx, J., 1971. Topography of the North Pacific: Institute of Marine Resources, University of California, San Diego.

Clague, D. A. and Jarrard, R. D., 1973. Tertiary Pacific plate motion deduced from the Hawaiian-Emperor chain: Geol. Soc. Am. Bull., v. 84, p. 1135-1154.
Grommé, S. and Vine, F. J., 1972. Paleomagnetism of Midway Atoll lavas and northward movement of the Pacific plate: Earth Planet. Sci. Lett., v. 17, p. 159-168.

Funkhouser, J. G., Barnes, I. L., and Naughton, J. J., 1968. The determination of a series of ages of Hawaiian volcanoes by the potassium-argon method: Pac. Sci., v. 22, p. 369-372.

Furumoto, A. S., Campbell, J.F., and Hussong, D. M., 1971. Seismic refraction surveys along the Hawaiian Ridge, Kauai to Midway Islands: Seis. Soc. Am. Bull., v. 61, p. 147-166.

Hays, J. D. and Pitman, W. C., III, 1973. Lithospheric plate motion, sea level changes, and climatic and ecological consequences: Nature, v. 246, p. 18-22.

Irving, E. and Couilliard, R. W., 1973. The Cretaceous normal polarity interval: Nature Phys. Sci., v. 244, p. 10-11.

Jackson, E. D., Silver, E. A., and Dalrymple, G. B., 1972. Hawaiian-Emperor chain and its relation to Cenozoic circumpacific tectonics: Geol. Soc. Am. Bull., v. 83, p. 601618.

Ladd, H. S., Tracey, J. I., Jr., and Gross, G. G., 1967. Drilling on Midway Atoll, Hawaii: Science, v. 156, p. 1088-1194.

Larson, R. L. and Chase, C. G., 1972. Late Mesozoic evolution of the Western Pacific: Geol. Soc. Am. Bull., v. 83, p. 3627-3644.

Larson, R. L. and Pitman, W. C., III, 1972. Worldwide correlation of Mesozoic magnetic anomalies, and its implications: Geol. Soc. Am. Bull., v. 83, p. 3645-3663.

Malahoff, A. and Woollard, G. P., 1968. Magnetic and tectonic trends over the Hawaiian Ridge. In Knopoff, L., Drake, C. L., and Hart, P. J. (Eds.), The crust and upper mantle of the Pacific area: Am. Geophys. Union Mono. 12, p. 241-276.

McDougall, I., 1964. Potassium-argon ages from lavas of the Hawaiian Islands: Geol. Soc. Am. Bull., v. 75, p. 107-128.

Moberly, R. and Khan, M. A., 1969. Interpretation of satellite-determined gravity anomalies: Nature, v. 223 , p. 263267.

Morgan, W. J., 1971. Convection plumes in the lower mantle: Nature, v. 230 , p. $42-43$.

1972. Plate motions and deep mantle convection. In Shagam, R. et al. (Eds.), Geol. Soc. Am. Mem. 132, p. 7-22.

Normark, W. R. and Shor, G. G., Jr., 1968. Seismic reflection study of the shallow structure of the Hawaiian Arch: J. Geophys. Res., v. 73, p. 6991-6998.

Shor, G. G., Jr., 1960. Crustal structure of the Hawaiian Ridge near Gardner Pinnacles: Seismol. Soc. Am. Bull., v. 50, p. 563-574.

Uyeda, S. and Miyashiro, A., 1974. Plate tectonics and the Japanese Islands: A Synthesis: Geol. Soc. Am. Bull., v. 85, p. $1159-1170$.

Wilson, J. T., 1963. A possible origin of the Hawaiian Islands: Canadian J. Phys., v. 41, p. 863-870.

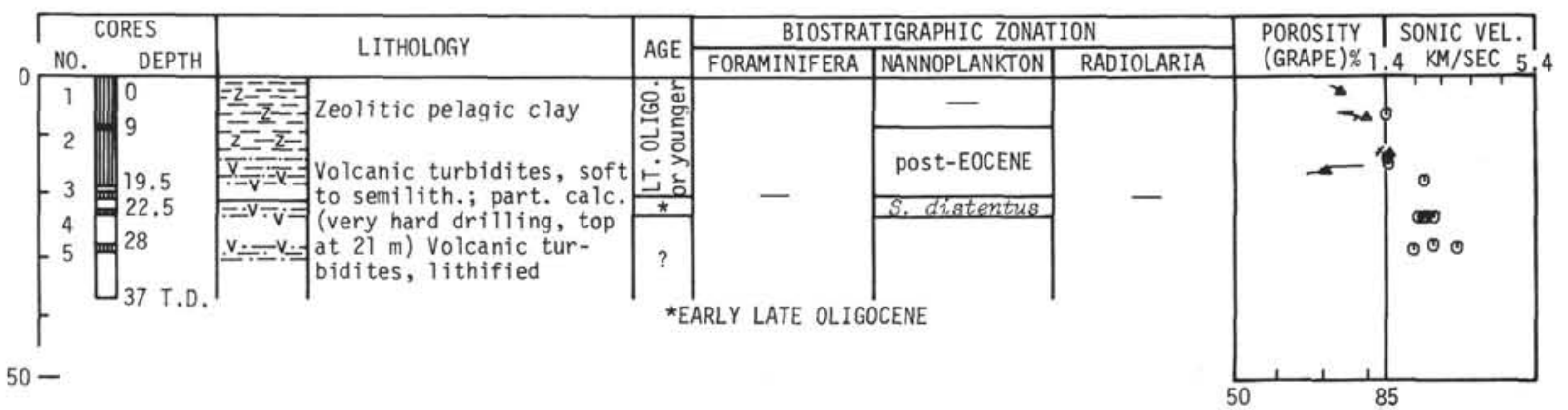

Figure 5. Summary of coring, lithology, biostratigraphy, and physical properties at Site 311. 


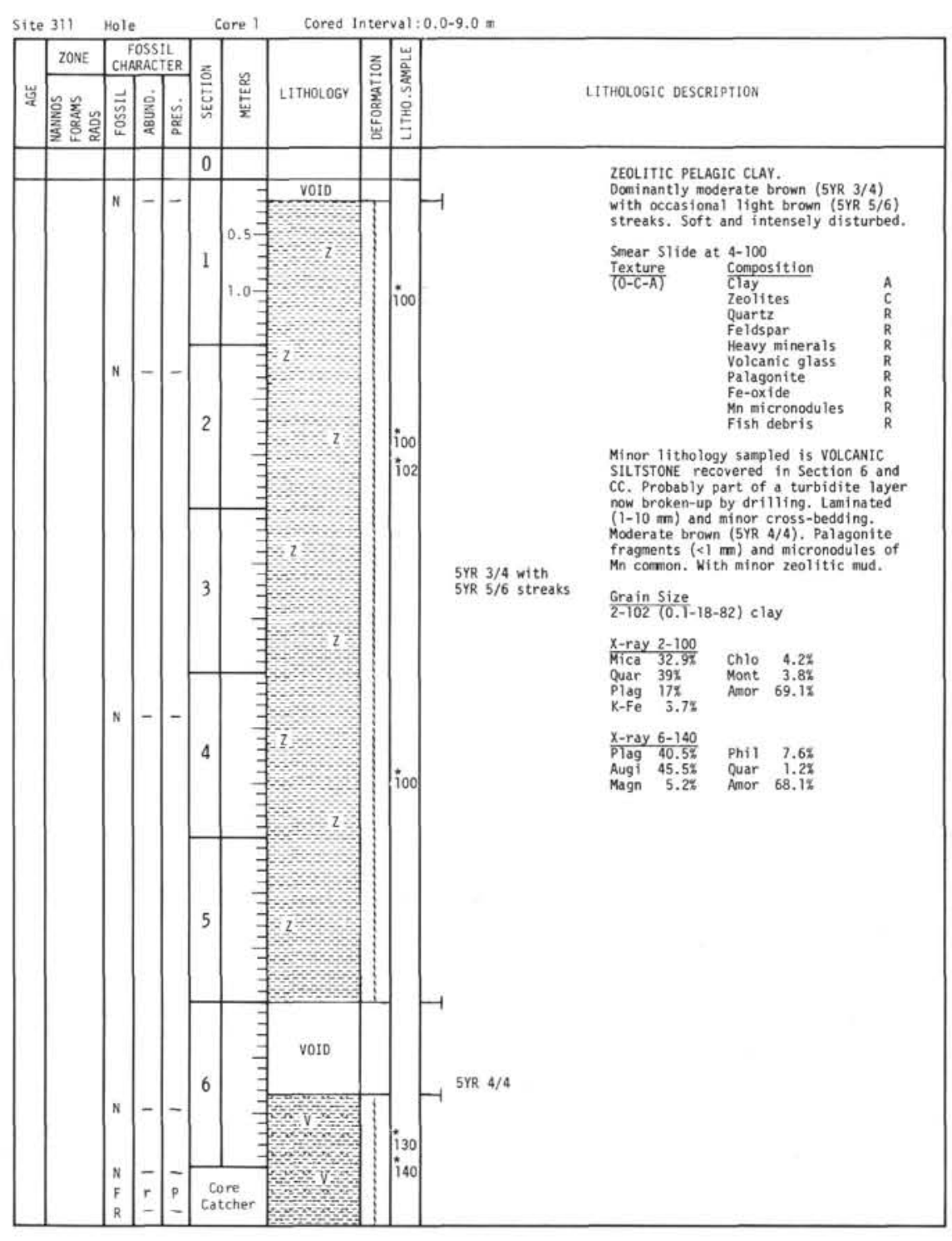

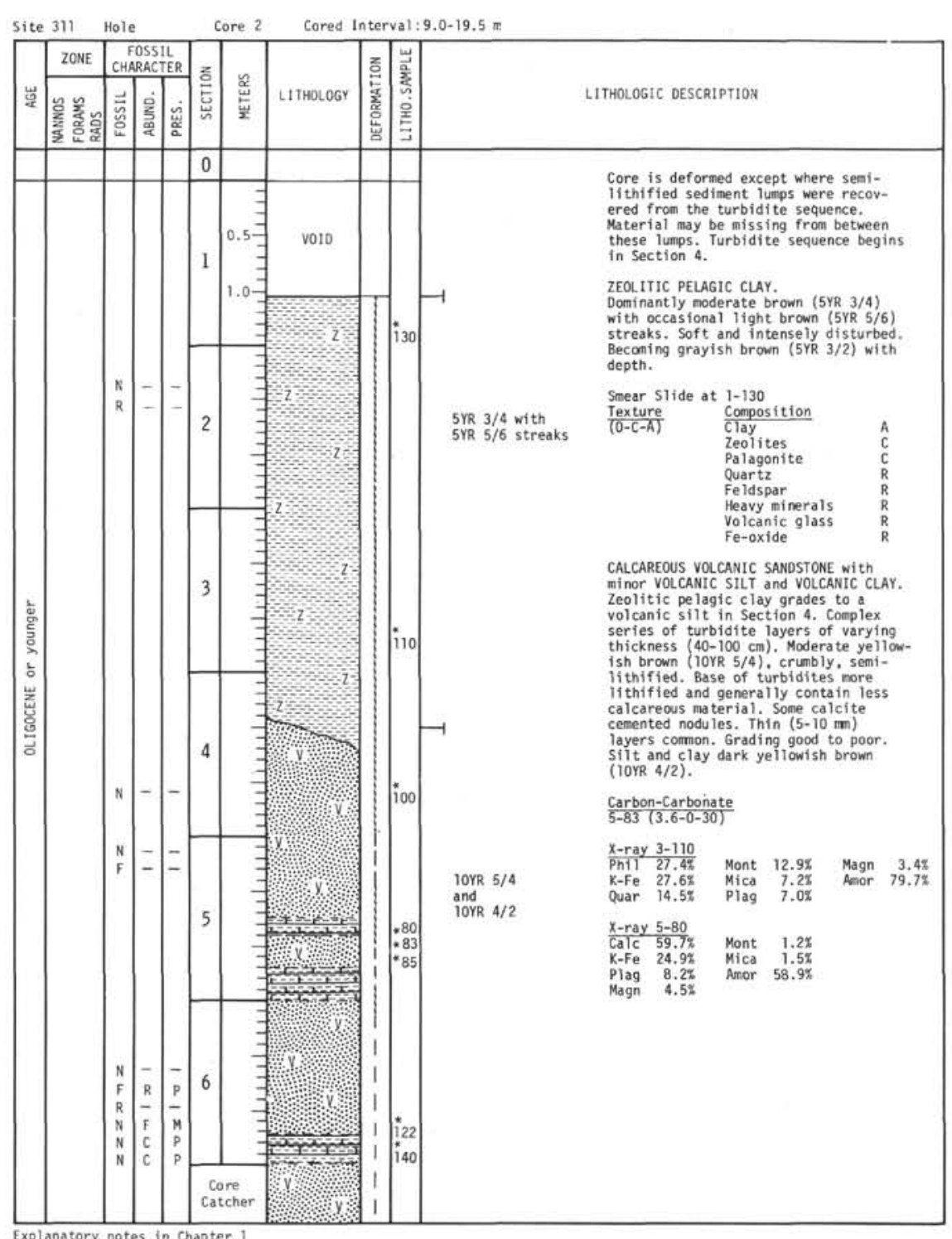




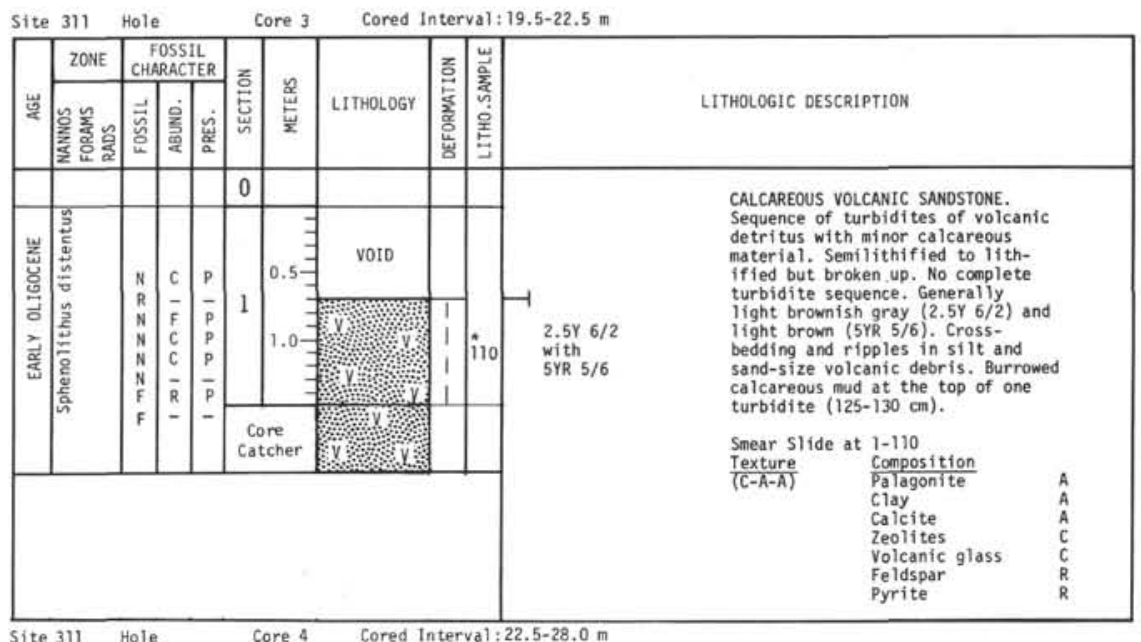

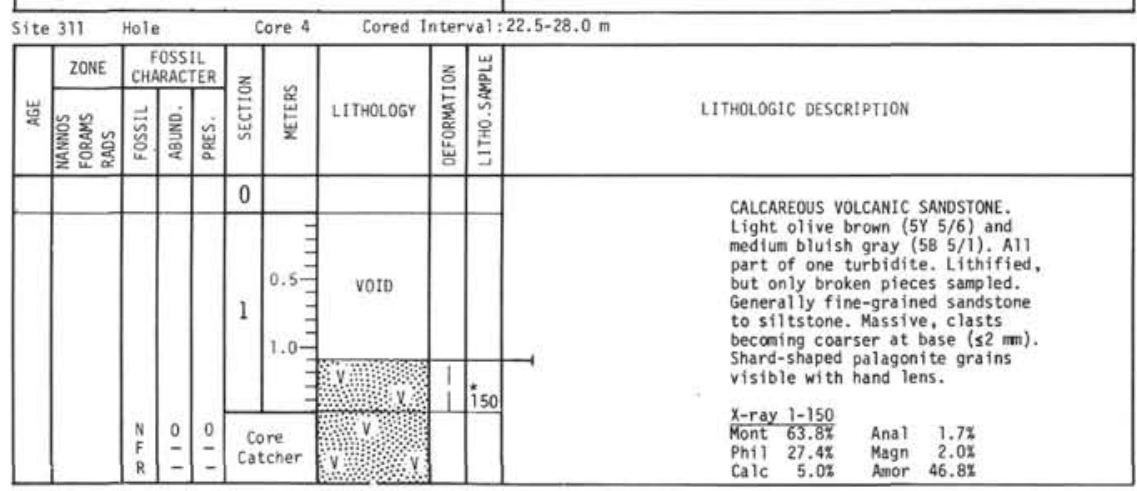

\begin{tabular}{|c|c|c|c|c|c|c|c|c|c|}
\hline \multicolumn{2}{|c|}{ Site 311} & tole & & \multicolumn{2}{|c|}{ core 5} & \multicolumn{3}{|c|}{ Cored Interval: $28.0-37.0 \mathrm{~m}$} & \multirow[b]{3}{*}{ LITHOLOGIC DESCRIPTION } \\
\hline \multirow{10}{*}{ 岁 } & ZONE & & & & & & z) & & \\
\hline & 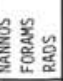 & $\begin{array}{l}\overrightarrow{\mathrm{u}} \\
\mathrm{u} \\
\end{array}$ & & & 葶 & LITHOLOGY & 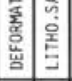 & & \\
\hline & & & & c & & & & \multirow{9}{*}{$\begin{array}{l}5 B G 3 / 2 \\
\text { and } 3 / 2 \\
5865 / 2\end{array}$} & \multirow{9}{*}{ 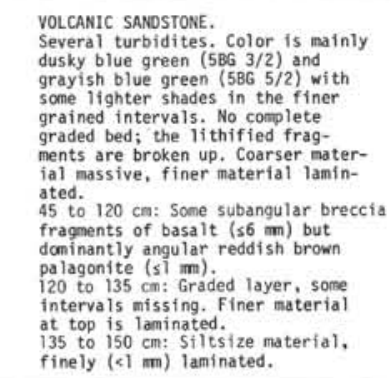 } \\
\hline & & & & & & voro & & & \\
\hline & & & & & $0.5=$ & & 1 & & \\
\hline & & & & 1 & & w & 1 & & \\
\hline & & & & & $1.0=$ & & 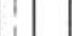 & & \\
\hline & & & & & & & 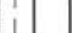 & & \\
\hline & & & & & & He & & & \\
\hline & & & & & otcher & $y=x$ & & & \\
\hline & & & & & & & & & \\
\hline
\end{tabular}


- Syringe porosity, \% COMPRESSIONAL SOUND VELOCITY

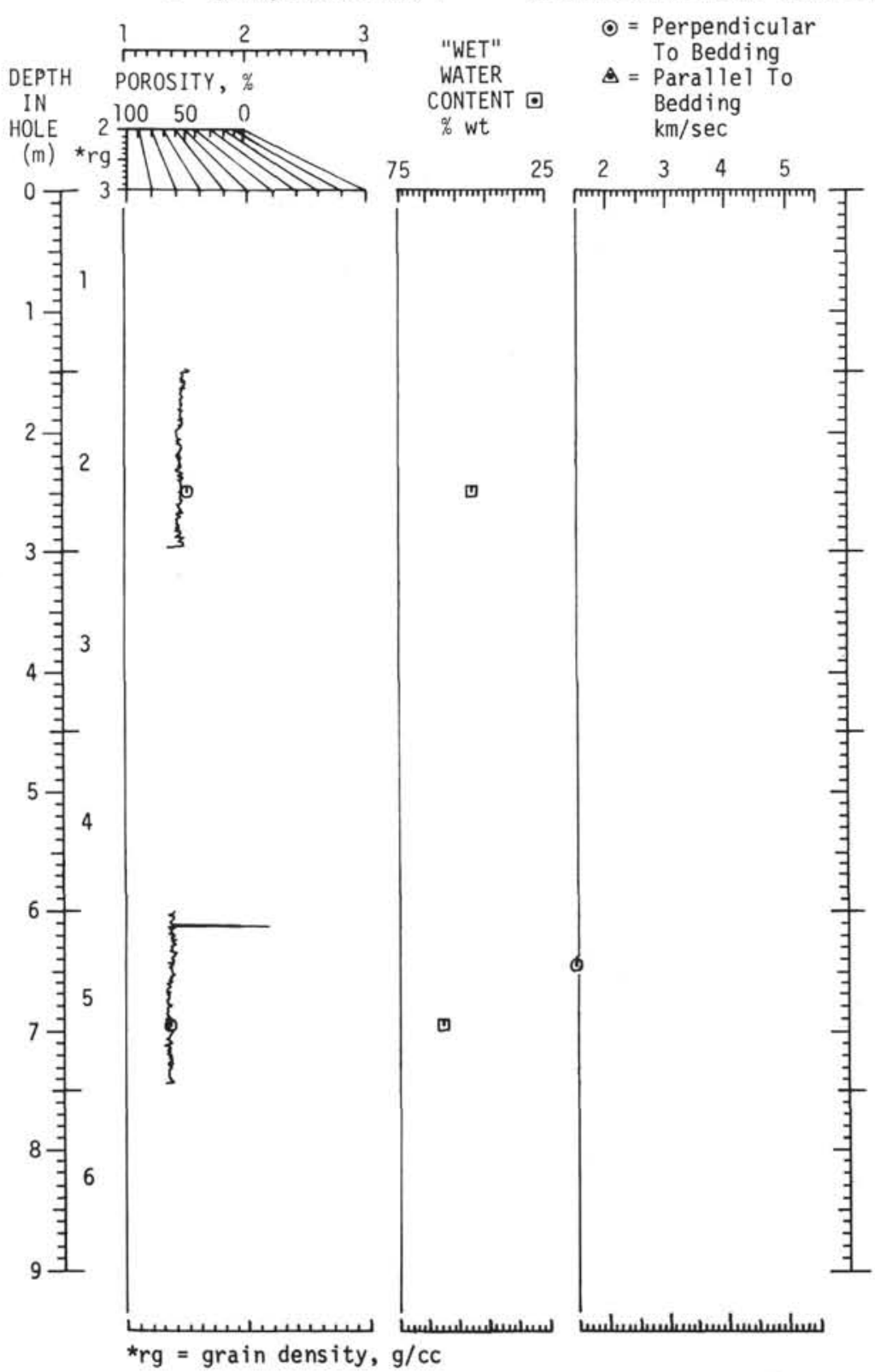

- Syringe porosity, \% COMPRESSIONAL SOUND VELOCITY

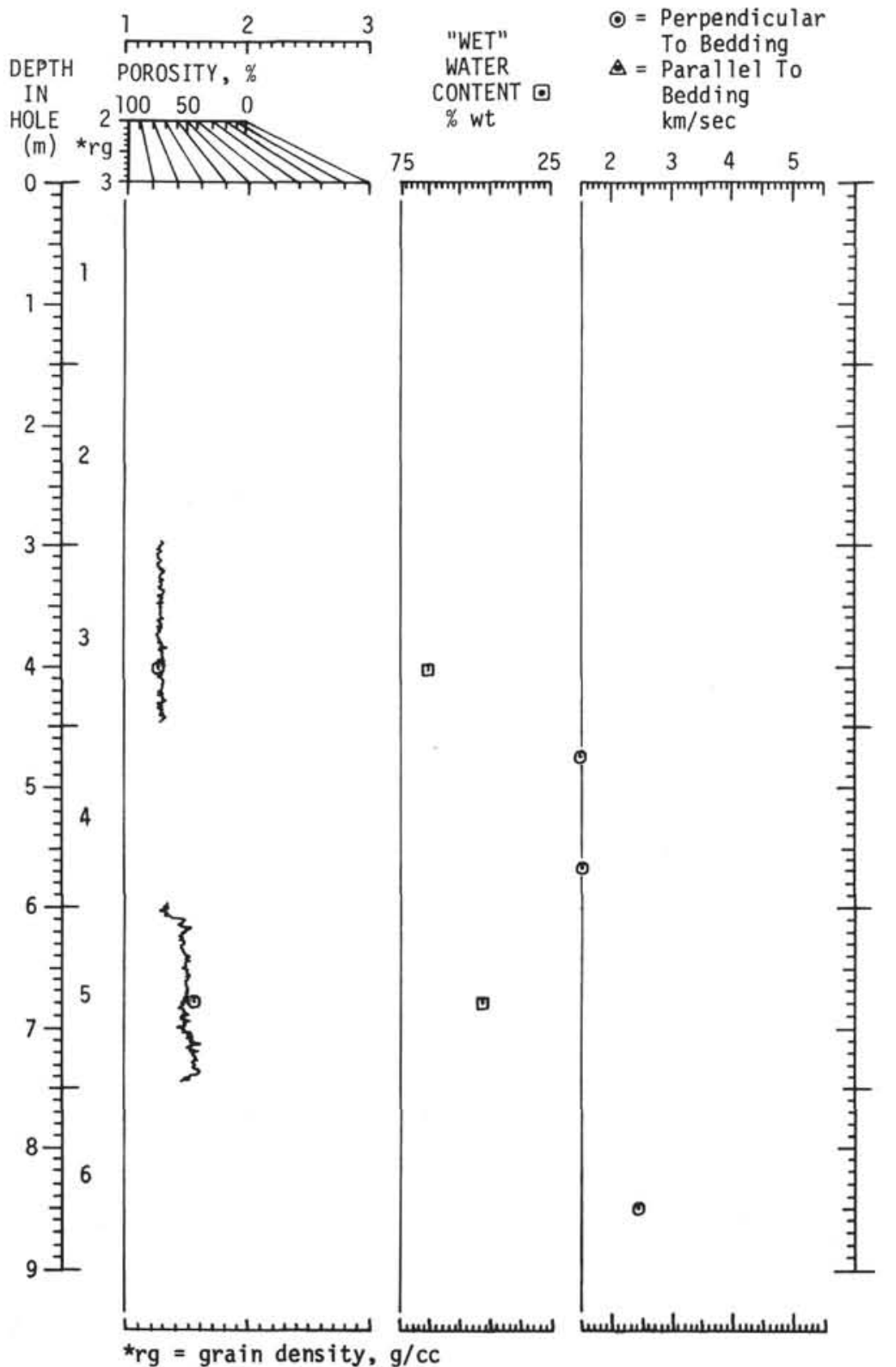


CORE $311-3$

- = GRAPE WET-BULK DENSITY, g/cC

- Syringe porosity, \% COMPRESSIONAL SOUND VELOCITY

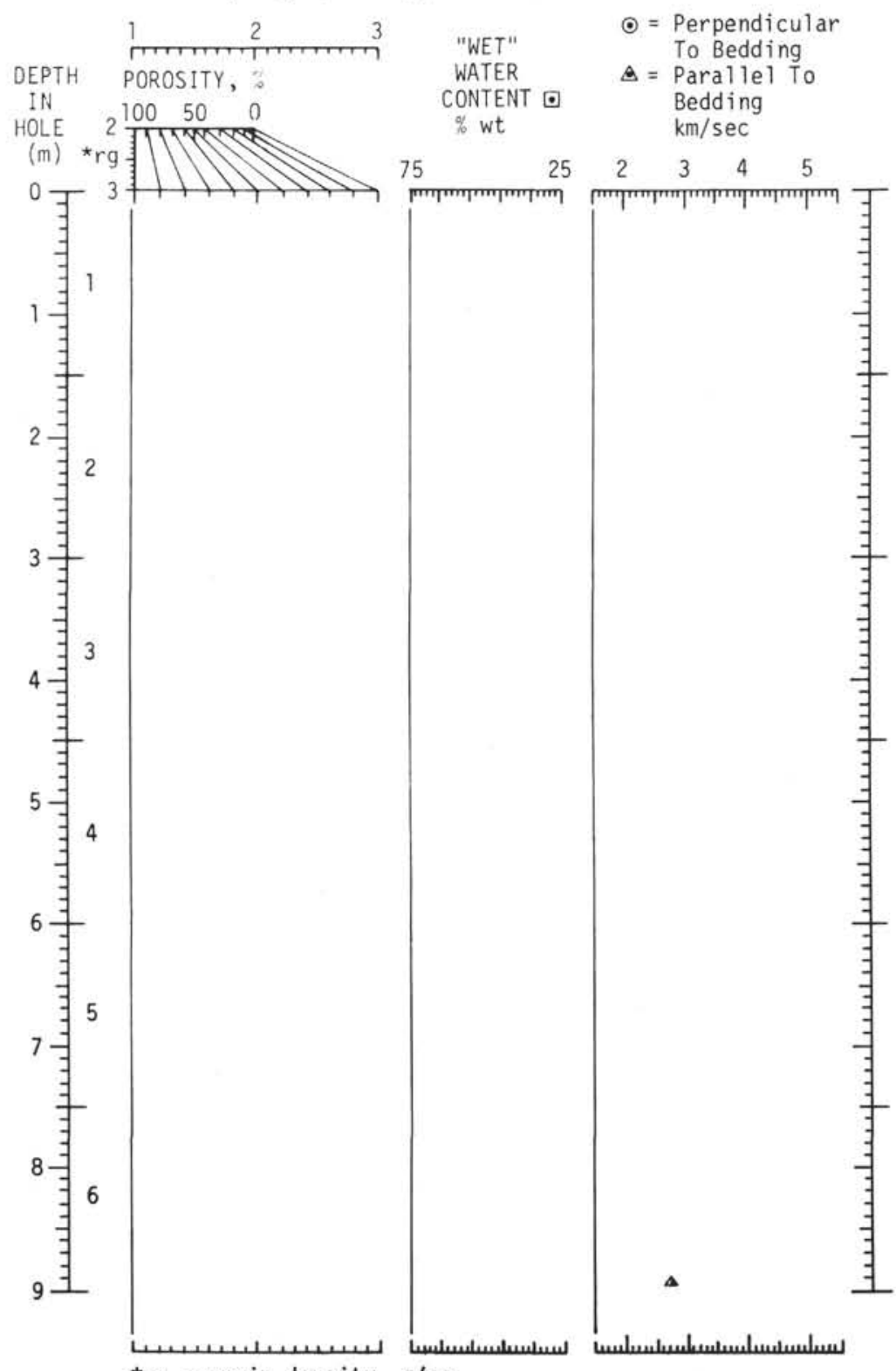

CORE 311-4

- $=$ GRAPE WET - BULK DENSITY, g/cc

- Syringe porosity, \%

COMPRESSIONAL SOUND VELOCITY

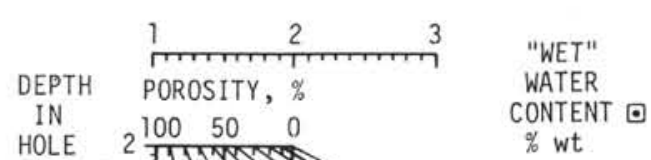

$\odot=$ Perpendicular

To Bedding

$\Delta=$ Parallel To Bedding

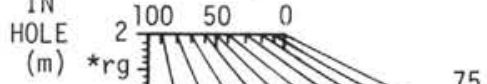

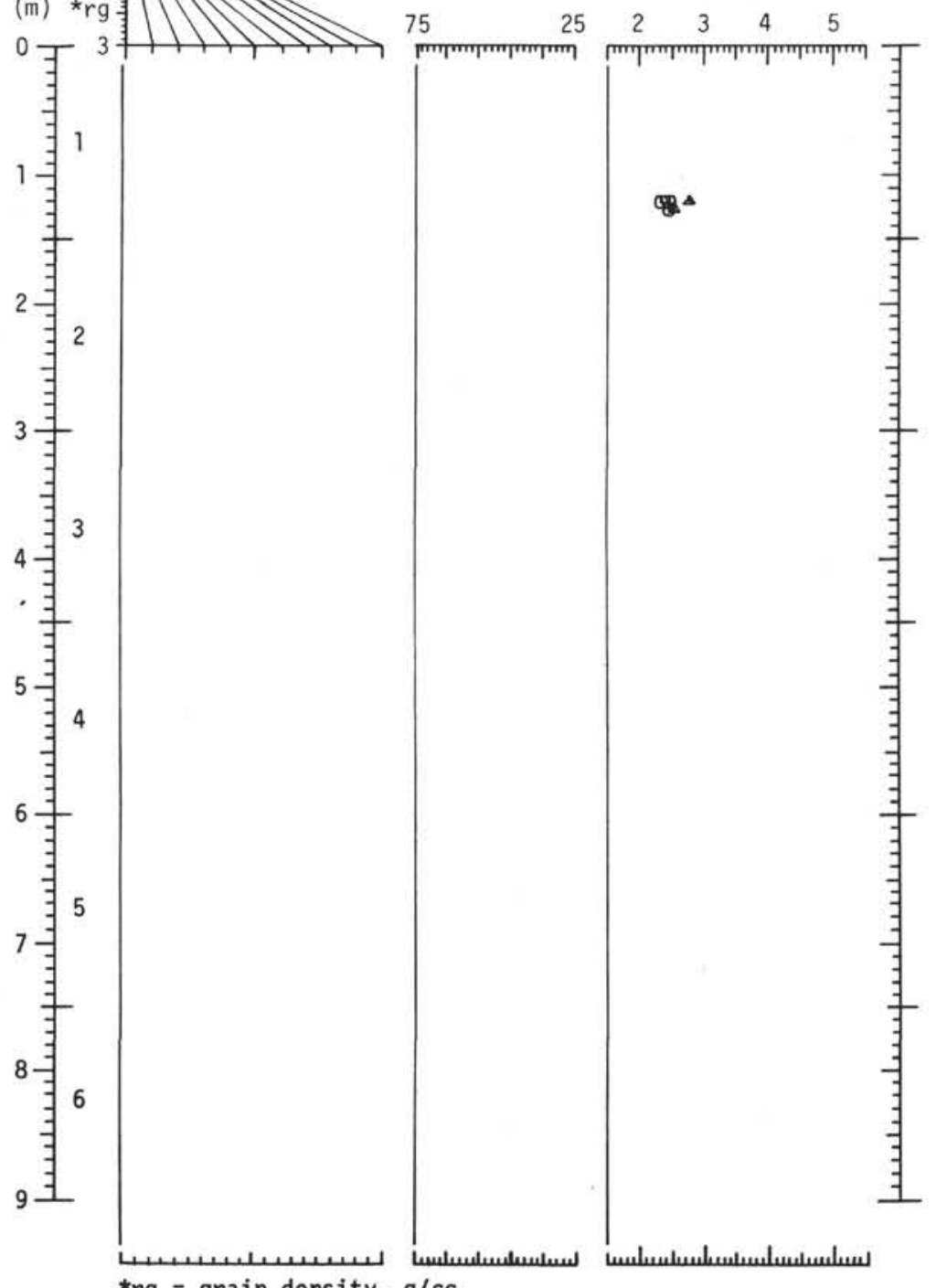


- Syringe porosity, \% COMPRESSIONAL SOUND VELOCITY

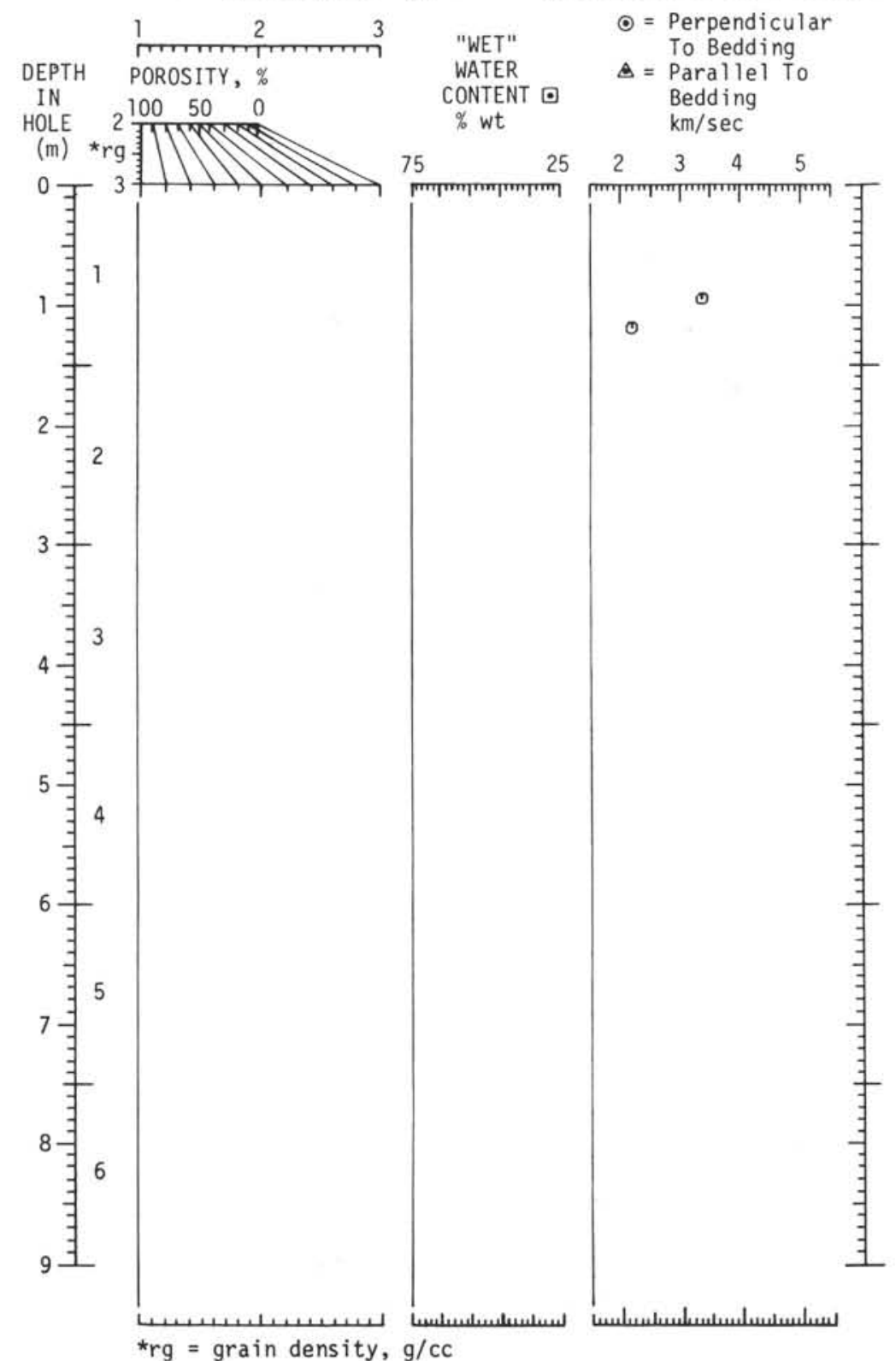




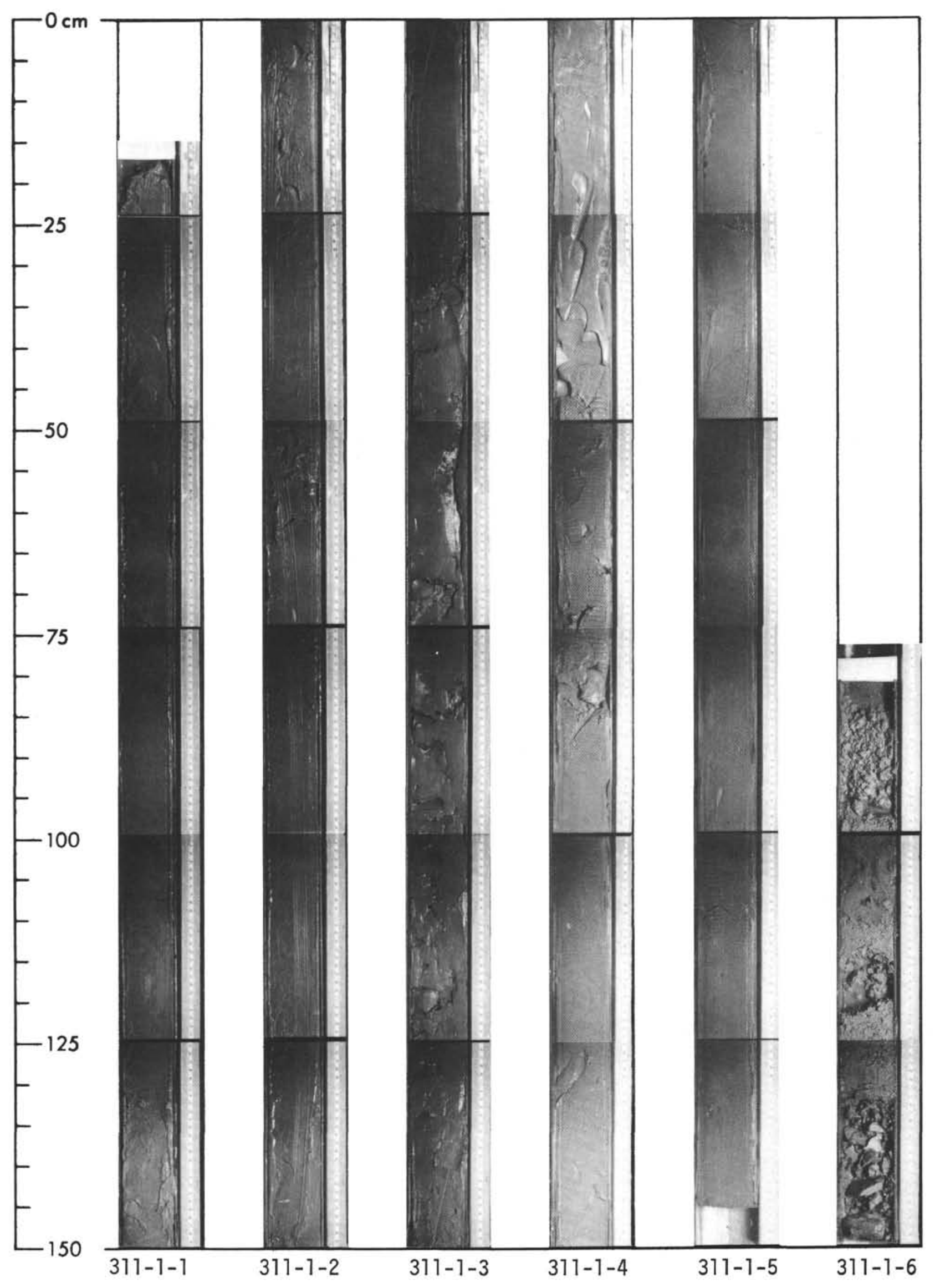


SITE 311

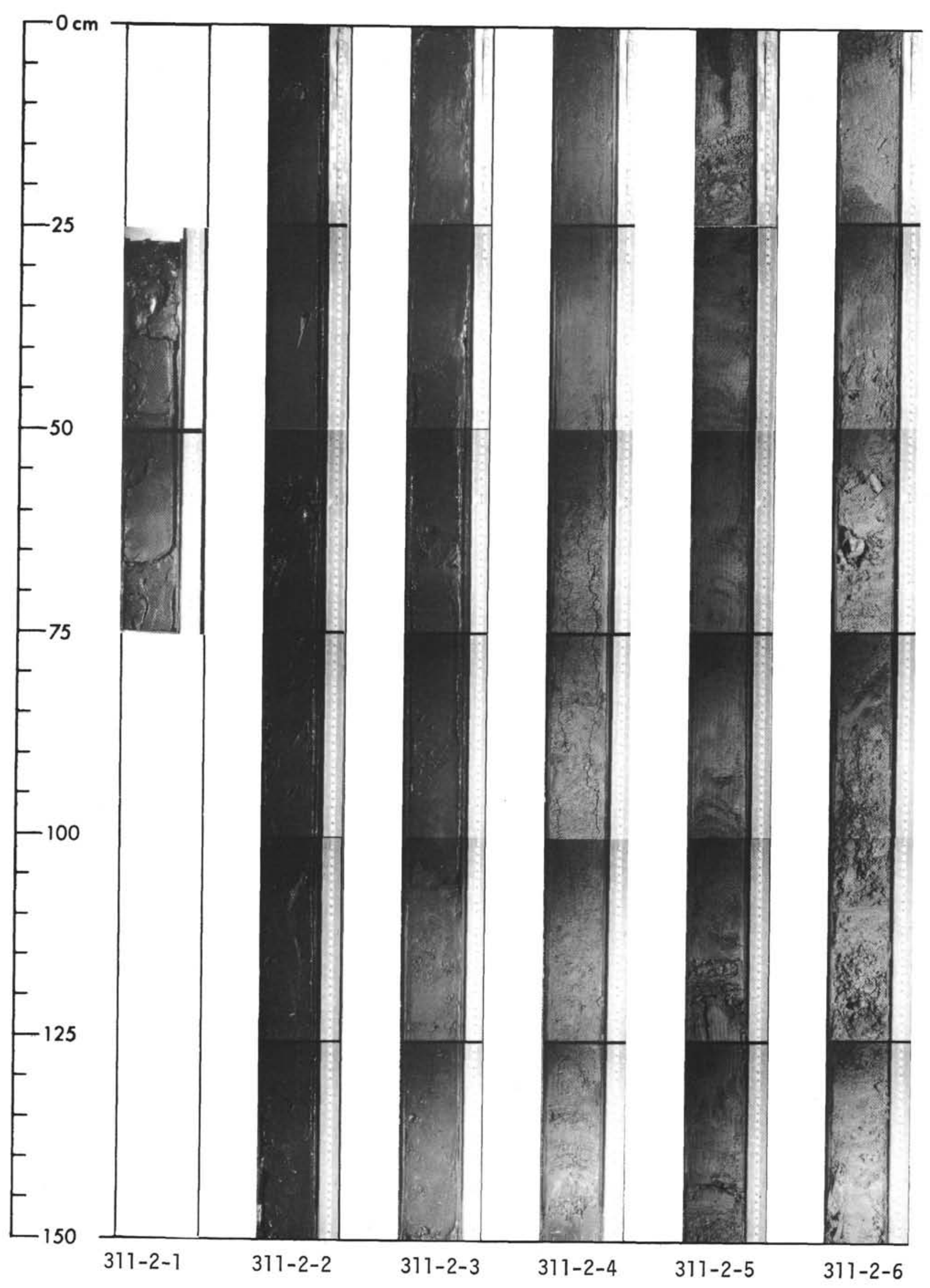




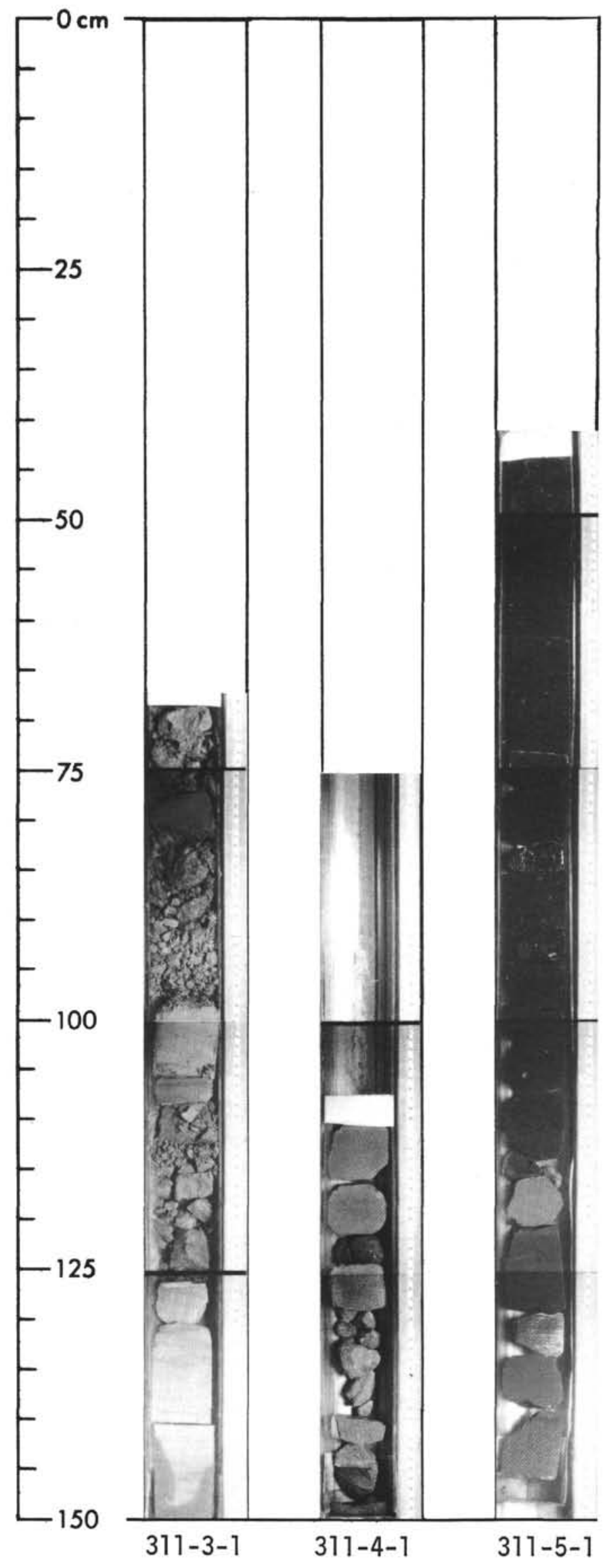

